\title{
GAMBARAN PEMANJANGAN INTERVAL QTC PADA TERAPI JANGKA PENDEK PASIEN TB MDR
}

\author{
Mifta Mansur $^{1)}$, Budi Suprapti ${ }^{1)}$, Movita Hidayati ${ }^{2)}$, Umi Fatmawati $^{3)}$ \\ ${ }^{1}$ Program Studi Magister Farmasi Klinik, Universitas Airlangga \\ ${ }^{2}$ SMF Paru, RS Paru Jember \\ ${ }^{3}$ Instalasi Farmasi, RS Dr. Soetomo Surabaya \\ Email: miftamansur@gmail.com
}

\begin{abstract}
Problems:Indonesia is one of 30 countries with a high burden of MDR-TB, with an estimated 23,000 (range, 16,000-31,000) cases, with a percentage of $8.8 \%$ (range, 6.2-12) for every 100,000 population. One of the challenges in MDR TB treatment is the high rate of side effects. In may 2016, WHO issued a recommendation the use of a standardized 9-11 months short-term therapy regimen. The side effect that can occure in this treatment combination is the prolongation of the QTc interval due to the administration of moxifloxacin (Mfx) and clofazimine (Cfz). The aim of the research: to determine the incidence of QTc interval prolongation in MDR-TB patients receiving short-term therapy regimen. Research method:This research is an observational study with retrospective data collection. Sampling was done by total sampling, obtained 51 subjects entered the exclusion criteria and there were 74 subjects who met the inclusion criteria. The results:there has been QTc interval prolongation with an average $31.31 \pm 43.471 \mathrm{~ms}$ from the baseline, the longest QTc interval value is $756 \mathrm{~ms}$ with a mean of $468,54 \pm 33,565 \mathrm{~ms}, 52(70,3 \%)$ subjects experienced QTc interval prolongation. Conclusions: There was QTc interval prolongation in MDR-TB patients with short-term therapy regimen.
\end{abstract}

Keywords: MDR TB, Moxifloxacin, Clofazimine, QTc Interval prolongation

\begin{abstract}
ABSTRAK
Permasalahan: Indonesia merupakan salah satu dari 30 negara dengan beban TB-MDR tinggi, diperkirakan terdapat 23.000 (kisaran, 16.000-31.000) kasus, dengan persentase 8,8\% (kisaran, 6,2-12) untuk setiap 100.000 populasi. Salah satu tantangan dalam pengobatan TB MDR adalah tingginya tingkat efek samping. Pada bulan Mei 2016 WHO mengeluarkan rekomendasi penggunaan paduan pengobatan standar jangka pendek 9-11 bulan. Efek samping yang dapat timbul pada paduan pengobatan ini adalah terjadinya pemanjangan interval QTc akibat pemberian moksifloksasin (Mfx) dan klofazimin (Cfz). Tujuan penelitian:untuk mengetahui kejadian pemanjangan interval QTc pada pasien TB MDR yang menerima regimen terapi jangka pendek. Metode penelitian:Penelitian ini merupakan penelitian observasional dengan pengambilan data secara retrospektif. Pengambilan sampel dilakukan secara total sampling, didapatkan 51 subyek masuk kriteria eksklusi dan terdapat 74 subyek yang memenuhi kriteria inklusi. Hasil:telah terjadi pemanjangan interval QTc rata- rata 31,31 $\pm 43,471 \mathrm{~ms}$ dari baseline, nilai interval QTc terpanjang $756 \mathrm{~ms}$ dengan rata-rata $468,54 \pm 33,565 \mathrm{~ms}$, sebanyak 52 $(70,3 \%)$ subyek mengalami efek samping interval QTc memanjang. Kesimpulan:Telah terjadi pemanjangan interval QTc pada pasien TB MDR dengan regimen terapi jangka pendek.
\end{abstract}

Kata Kunci : TB MDR, Moksifloksasin, Klofazimin, Pemanjangan Interval QTC 



\section{PENDAHULUAN}

Multidrug-resistant TB (MDR-TB/TB MDR) merupakan penyakit tuberkulosis (TB) dimana bakteri tidak lagi merespon atau mengalami resistensi terhadap dua obat anti tuberkulosis (OAT) yang paling utama, isoniazid dan rifampin (WHO, 2018). Menurut Kementerian Kesehatan RI, TB MDR adalah terjadinya resistensi terhadap isoniazid dan rifampisin, dengan atau tanpa OAT lini pertama yang lain, misalnya resisten HR, HRE, HRES (Kemenkes, 2014).

Secara global pada tahun 2017, diperkirakan ada 558.000 kasus baru (kisaran, 483.000-639.000) rifampicin resistant TB (RR-TB). Dari jumlah tersebut, diperkirakan bahwa $82 \%$ merupakan kasus TB MDR. Indonesia sendiri merupakan salah satu dari 30 negara dengan beban TB-MDR tinggi, diperkirakan terdapat 23.000 (kisaran, 16.00031.000) kasus, dengan persentase 8,8\% (kisaran, 6,2-12) untuk setiap 100.000 populasi (WHO, 2018). Untuk di Jember pada tahun 2017 ditemukan penderita TB sebanyak 3.497 pasien dengan penderita TB MDR sebanyak 225 pasien. Jumlah penderita TB MDR ini meningkat dibandingkan tahun 2013 dimana hanya ditemukan 6 pasien.

Salah satu tantangan dalam pengobatan TB MDR adalah tingginya tingkat efek samping. Karena dibutuhkan setidaknya empat obat aktif untuk merancang regimen pengobatan yang efektif (Falzon, et al., 2017). Pada bulan Mei 2016 WHO mengeluarkan rekomendasi penggunaan paduan pengobatan standar jangka pendek 9-11 bulan untuk tiga kelompok pasien, yaitu: pasien rifampicin resistant TB (RR-TB) atau MDR yang belum pernah diobati dengan OAT lini kedua; atau pada pasien yang kemungkinan kecil terjadi resistensi; atau terbukti tidak resisten terhadap fluorokuinolon dan obat injeksi lini kedua. Paduan pengobatan ini terdiri dari 4-6 bulan fase awal kanamisin-moksifloksasin-etionamid (protionamid)-isoniazid dosis tinggi-clofazimin-etambutol-pirazinamid dan 5 bulan fase lanjutan moksifloksasin-clofazimin-etambutol-pirazinamid (4-6 Km - Mfx - Eto (Pto) - H (DT) - Cfz $-\mathrm{E}-\mathrm{Z} / 5 \mathrm{Mfx}-\mathrm{Cfz}-\mathrm{E}-\mathrm{Z}$ ) (WHO, 2016). Efek samping yang dapat timbul pada paduan pengobatan ini adalah terjadinya pemanjangan interval QT akibat pemberian moksifloksasin (Mfx) dan klofazimin (Cfz) (Yoon, et al., 2017).

Moksifloksasin merupakan OAT golongan kuinolon yang bekerja dengan menghambat DNA girase dan topoisomerase IV pada bakteri. Moksifloksasin dapat 
melawan bakteri gram positif, gram negatif, beberapa bakteri anaerob dan beberapa organisme seperti Chlamydia, Mycoplasma, dan Mycobacterium (AHFS, 2011). Efek samping yang mungkin terjadi pada penggunaan moksifloksasin antara lain toksisitas gastrointestinal, efek pada sistem saraf pusat, ruam, dysglycemia, tendonitis, ruptur tendon, pemanjangan interval QT dan hepatotoksisitas (Nahid, et al., 2016). Obat lain yang berpotensi menyebabkan pemanjangan interval QT yang diberikan dalam paduan terapi jangka pendek ini adalah klofazimin. (Wallis. R, 2016). Mekanisme pemanjangan interval QT yang diinduksi obat terjadi akibat pemblokiran voltage-gated potassium channels, terutama komponen cepat dari arus kalium rectifier tertunda IKr, yang diekspresikan oleh HERG (the human ether-a-go-go-related gene) menghasilkan akumulasi kalium dalam miosit yang dapat menyebabkan repolarisasi jantung tertunda (Ponte, et al., 2010)

Interval QT adalah ukuran EKG yang mengkuantifikasi aliran arus ion yang melintasi membran sel miosit ventrikel. Aliran ion melintasi miosit ventrikel terjadi melalui spesialisasi saluran protein. Ketika saluran ini mengalami kegagalan fungsi, dapat mengganggu irama jantung normal dan menimbulkan risiko pasien terkena aritmia jantung. Interval QT diukur pada standard 12-lead EKG dengan mengukur interval dari awal kompleks QRS hingga akhir gelombang T (Harausz, et al., 2015). Pemanjangan interval QT yang diinduksi obat dikaitkan dengan terjadinya polymorphic ventricular tachycardia yang dikenal sebagai torsade de pointes (Choi, et al., 2015). Pemanjangan interval QT merupakan faktor risiko penting terjadinya aritmia ventrikel dan kematian akibat serangan jantung mendadak. Interval QT yang memanjang didefinisikan di atas $450 \mathrm{~ms}$ pada pria, dan di atas 470 ms pada wanita (Niemeijer, et al., 2015).

RS Paru Jember merupakan rumah sakit rujukan pengobatan TB MDR yang melayani pengobatan pasien TB MDR. Salah satu paduan pemberian OAT yang diberikan mengikuti rekomendasi paduan pengobatan standar jangka pendek 9-11 bulan dari WHO. Berdasarkan survey awal didapatkan pemeriksaan EKG secara rutin telah dilakukan sebagai salah satu bentuk monitoring dan evaluasi namun belum terdapat data gambaran kejadian efek samping. Pada penelitian ini akan dilakukan analisis untuk mengetahui gambaran kejadian pemanjangan interval QTc pada regimen terapi jangka pendek pasien TB MDR di RS Paru Jember. 


\section{METODE PENELITIAN}

Penelitian ini merupakan penelitian observasional dengan pengambilan data secara retrospektif. Penelitian dilakukan di Klinik TB MDR RS Paru Jember selama periode Juni sampai dengan Agustus 2020. Subyek penelitian pasien TB MDR di klinik TB MDR RS Paru Jember periode Juni 2018 hingga Desember 2019 dan memenuhi kriteria inklusi yaitu pasien TB MDR usia $\geq 15$ th, mendapatkan kombinasi moksifloksasin dan klofazimin dalam regimen terapi jangka pendek dan memiliki data pemeriksaan EKG lengkap. Pengambilan sampel dilakukan secara total sampling. Data diolah secara statistik deskriptif dan disajikan dalam bentuk tabel.

\section{HASIL}

Pada penelitian ini terdapat 125 subyek yang mendapatkan moksifloksasin dan klofazimin dalam regimen terapi jangka pendek, dimana 74 subyek memenuhi kriteria inklusi. Karakteristik awal subyek dapat dilihat pada Tabel 1.

Tabel 1 Karakteristik Awal Subyek Penelitian

\begin{tabular}{lcc}
\hline Karakteristik & Jumlah $(\mathbf{n}=\mathbf{7 4})$ & Persentase $\mathbf{\%})$ \\
\hline Jenis Kelamin & & \\
$\quad$ Laki-laki & 42 & 56,8 \\
$\quad$ Perempuan & 32 & 43,2 \\
Usia (tahun) & & \\
$15-40$ & 31 & 41,9 \\
$41-65$ & 39 & 52,7 \\
$>65$ & 4 & 5,4 \\
Berat Badan (kg) & & \\
$<33$ & 3 & 4,1 \\
$33-50$ & 47 & 63,5 \\
$>50$ & 24 & 32,4 \\
\hline
\end{tabular}

Tabel 1 menunjukkan jumlah subyek penelitian laki-laki lebih banyak (56,8\%) dibanding perempuan $(43,2 \%)$, sebanyak 52,7\% termasuk dalam kelompok usia 41-65 tahun, 41,9\% kelompok usia 15-40 tahun, dan 5,4\% kelompok usia >65 tahun. Untuk karakteristik berat badan sebanyak 63,5\% memiliki berat badan diantara $33-50 \mathrm{~kg}, 32,4 \%$ memiliki berat badan $>50 \mathrm{~kg}$ dan $4,1 \%$ memiliki berat badan $<33 \mathrm{~kg}$. 

Pengukuran interval QTc dilakukan setiap satu bulan sekali selama pengobatan TB MDR dengan regimen jangka pendek. Setelah dilakukan analisis deskriptif terhadap interval QTc didapatkan nilai minimal, maksimal dan rata-rata interval QTc dan perubahan interval QTc $(\Delta \mathrm{QTc})$ setiap bulannya serta persentase kejadian efek samping interval QTc memanjang.

Tabel 2 Hasil Pengukuran Interval QTc

\begin{tabular}{lcccccccc}
\hline & \multicolumn{4}{c}{ Nilai Interval QTc (ms) } & \multicolumn{7}{c}{ Nilai Perubahan Interval QTc (ms) } \\
\cline { 2 - 9 } $\begin{array}{l}\text { Waktu } \\
\text { Pengukuran }\end{array}$ & Min & Max & Mean & $\begin{array}{c}\text { Std. } \\
\text { Deviation }\end{array}$ & Min* & Max & Mean & Std. Deviation \\
\hline Baseline & 376 & 484 & 433.15 & 21.057 & & & & \\
Bulan 1 & 327 & 756 & 462.35 & 53.452 & -121 & 299 & 29,43 & 48,642 \\
Bulan 2 & 400 & 535 & 456.62 & 28.152 & -110 & 130 & 2,48 & 37,204 \\
Bulan 3 & 377 & 512 & 455.09 & 28.817 & -117 & 70 & $-2,58$ & 32,885 \\
Bulan 4 & 388 & 573 & 461.37 & 31.374 & -61 & 111 & 6,54 & 38,132 \\
Bulan 5 & 403 & 554 & 462.59 & 32.380 & -136 & 106 & $-2,34$ & 41,256 \\
Bulan 6 & 416 & 588 & 468.54 & 33.565 & -104 & 148 & 9,11 & 41,232 \\
Bulan 7 & 399 & 537 & 452.06 & 35.141 & -141 & 68 & $-17,06$ & 43,61 \\
Bulan 8 & 388 & 566 & 458.34 & 35.851 & -141 & 121 & $-10,52$ & 42,865 \\
Bulan 9 & 398 & 488 & 453.53 & 24.469 & -75 & 84 & 5,89 & 32,757 \\
Bulan 10 & 417 & 500 & 454.86 & 23.461 & -112 & 37 & $-7,45$ & 34,299 \\
Bulan 11 & 403 & 548 & 456.36 & 47.022 & -59 & 73 & $-5,27$ & 40,073 \\
\hline
\end{tabular}

Keterangan : *tanda negatif menunjukkan interval QTC lebih pendek dari pengukuran sebelumnya

Tabel 2 menunjukkan interval QTc baseline terkecil $376 \mathrm{~ms}$, terbesar $484 \mathrm{~ms}$ dengan rata-rata 433,15 $\pm 21,057 \mathrm{~ms}$. Setelah pengobatan, interval QTc terkecil $327 \mathrm{~ms}$ dan terbesar $756 \mathrm{~ms} . \Delta \mathrm{QTc}$ terkecil $-141 \mathrm{~ms}$ dan terbesar $299 \mathrm{~ms}$ dengan rata-rata terbesar $29,43 \pm 48,642 \mathrm{~ms}$.

Tabel 3 Persentase Kejadian Efek Samping Interval QTc Memanjang

\begin{tabular}{ccc}
\hline Kategori & Jumlah & Persentase \\
\hline Ya & 52 & $70,3 \%$ \\
Tidak & 22 & $29,7 \%$ \\
Total & $\mathbf{7 4}$ & $\mathbf{1 0 0 \%}$ \\
\hline
\end{tabular}

Keterangan : Persentase terhadap total 74 pasien

Pada Tabel 3, dapat dilihat bahwa sebanyak 52 (70,3\%) subyek penelitian mengalami kejadian efek samping interval QTc memanjang dan $22(29,7 \%)$ subyek 
penelitian tidak mengalami efek samping interval QTc memanjang selama menjalani pengobatan.

\section{PEMBAHASAN}

Dari 74 subyek terdapat $42(56,8 \%)$ subyek dengan jenis kelamin laki-laki dan 32 $(43,2 \%)$ subyek perempuan. Laki -laki cenderung lebih rentan terhadap faktor risiko TB, hal ini dikarenakan laki-laki memiliki aktivitas yang lebih tinggi sehingga transmisi penyakit mudah terjadi. Selain itu beban kerja, istirahat kurang, mobilisasi tinggi dan gaya hidup yang tidak sehat seperti merokok dan minum alkohol dapat menjadi faktor risiko yang dapat menurunkan kekebalan tubuh sehingga rentan terkena (Kondoy dkk., 2014). Penelitian dari Thomakos et al (2013) menyebutkan bahwa pasien yang memiliki diabetes melitus dan kebiasaan merokok akan semakin menambah risiko terjadi pemanjangan interval QTc. Berdasarkan kategori usia, kelompok usia 41-65 tahun merupakan kelompok usia terbanyak $(52,7 \%)$. Hal ini terkait penurunan sistem imun dengan bertambahnya usia, sehingga sangat rentan terhadap berbagai penyakit termasuk Tuberkulosis (Widoyono, 2011).

Pemanjangan interval QT merupakan faktor risiko penting terjadinya aritmia ventrikel dan kematian akibat serangan jantung mendadak. Pemanjangan interval QT yang diinduksi obat dikaitkan dengan terjadinya polymorphic ventricular tachycardia yang dikenal sebagai torsade de pointes (Choi, et al., 2015). Disebutkan bahwa pasien dengan nilai interval QTc $500 \mathrm{~ms}$ memiliki risiko 1,66 kali lebih besar mengalami kejadian jantung terkait interval QTc dibandingkan pasien dengan nilai interval QTc $400 \mathrm{~ms}$, sedangkan pasien dengan interval QTc 550 ms memiliki risiko 2,14 kali lipat lebih besar (Beach, et al., 2013).

Nilai interval QTc terkecil pada penelitian ini $327 \mathrm{~ms}$ terjadi pada bulan pertama dan terbesar $756 \mathrm{~ms}$ juga pada bulan pertama. $\Delta$ QTe terkecil $-141 \mathrm{~ms}$ pada bulan ketujuh dan terbesar 299 ms pada bulan pertama (Tabel 2). Untuk prevalensi kejadian efek samping interval QTc memanjang terjadi pada 52 subyek dengan persentase 70,3\% (Tabel 3). Pada penelitian tentang kejadian pemanjangan interval QT pada pasien TB MDR dan non TB, perubahan interval QTcF yang signifikan (grade 3 atau lebih dengan QTcF > $500 \mathrm{~ms}$ atau peningkatan $>60 \mathrm{~ms}$ ) 
diamati pada 10/60 pasien (17\%) tanpa kejadian klinis (Yoon, et. al., 2017). Penelitian lain pada subyek sehat, moksifloksasin memperpanjang interval QTc sebesar 11,5-19,5 ms. Pemanjangan interval QTc yang cukup besar (30-60ms) juga telah dilaporkan pada beberapa pasien, misalnya kejadian pemanjangan interval QTc $(30-60 \mathrm{~ms})$ pada pasien pneumonia usia lanjut adalah 15,5\% (Khan. et. al., 2018). Disebutkan bahwa rata-rata pemanjangan interval QT 17 ms pada pemberian klofazimin tunggal setelah 14 hari (Diacon, et. al., 2015).

Pemanjangan interval QTc dapat terjadi akibat diinduksi oleh penggunaan obat, dalam hal ini akibat penggunaan moksifloksasin dan klofazimin. Moksifloksasin dan klofazimin diketahui dapat meningkatkan interval QTc melalui blokade voltage-gated potassium channel, terutama komponen cepat dari arus kalium rectifier tertunda (Ikr) yang diekspresikan oleh HERG menghasilkan akumulasi kalium dalam miosit (Briasoulis. et al., 2010). Diketahui bahwa penggunaan obat yang berpotensi memperpanjang interval QTc secara bersama dalam hal ini moksifloksasin dan klofazimin, akan meningkatkan potensi risiko terjadinya pemanjangan interval QTc. Faktor risiko lain yang dapat dievaluasi pada subyek penelitian diantaranya jenis kelamin perempuan, usia, diabetes, kadar albumin rendah, ketidakseimbangan elektrolit dan obat yang berpotensi menyebabkan hipotiroidisme (Ramachandran \& Swaminathan, 2015; Pranger, 2018).

TB MDR sering disertai dengan DM sebagai komorbid yang berperan penting pada progresivitas penyakit. Hiperglikemia pada pasien DM dapat menurunkan respon imunologik sehingga memudahkan berkembangnya penyakit infeksi TB (Mihardja, et al, 2015). Ketidakseimbangan elektrolit terutama hipokalemi merupakan kondisi yang sering terjadi pada pasien TB MDR yang menjalani pengobatan. Hal ini dapat terjadi akibat pengaruh efek samping obat. Penggunaan kanamisin dalam terapi diketahui dapat menyebabkan gangguan elektrolit. Hipokalemi dapat terjadi juga akibat efek samping mual dan muntah yang cukup berat pada pengobatan TB MDR. Kondisi ini menyebabkan intake kalium yang rendah dan menyebabkan hipokalemi (Suparyatmo, 2014). Diperlukan penelitian lebih lanjut pengaruh faktor risiko terhadap pemanjangan interval QTc. 


\section{KESIMPULAN}

Telah terjadi pemanjangan interval QTc pada pasien TB MDR yang mendapatkan moksifloksasin dan klofazimin pada terapi jangka pendek. Interval QTc terkecil $327 \mathrm{~ms}$ dan terbesar $756 \mathrm{~ms} . \triangle \mathrm{QTc}$ terkecil $-141 \mathrm{~ms}$ dan terbesar $299 \mathrm{~ms}$ dengan rata-rata terbesar $29,43 \pm 48,642$ ms. Sebanyak 52 (70,3\%) subyek penelitian mengalami kejadian efek samping interval QTc memanjang. Diperlukan monitoring dan evaluasi terhadap interval QTc pada pengobatan regimen jangka pendek pasien TB MDR.

Penelitian selanjutnya disarankan untuk menggunakan lebih dari satu tempat penelitian untuk menjamin ketersediaan subyek penelitian dan menganalisa secara statistik hubungan jenis kelamin, usia, status merokok, alkohol, tekanan darah, kadar elektrolit, kadar gula darah, kadar trigliserida dan kadar magnesium sebagai faktor risiko pemanjangan interval QTc yang dapat dievaluasi pada subyek penelitian.

\section{DAFTAR PUSTAKA}

AHFS, 2011. AHFS Drug Information Essentials. 8th penyunt. Bethesda, Maryland: American Society of Health-System Pharmacists, Inc.

Beach, S. et al., 2013. QTc Prolongation, Torsades de Pointes, and psychotropic medications. Psychosomatics, Volume 54, pp. 1-13. doi: HYPERLINK "https://doi.org/10.1016/j.psym.2012.11.001" It "_blank" 10.1016/j.psym.2012.11.001

Briasoulis, S., Agarwal, V. \& Pierce, W., 2011. QT prolongation and torsade de pointes induced by fluoroquinolones: infrequent side effects from commonly used medications. Cardiology, 120(2), pp. 103-110. HYPERLINK "https://doi.org/10.1159/000334441" doi.org/10.1159/000334441

Choi, H. et al., 2015. Population Pharmacokinetic-Pharmacodynamic Analysis to Compare the Effect of Moxifloxacin on QT Interval Prolongation Between Healthy Korean and Japanese Subjects. Clinical therapeutics, 38(12), pp. 2610-2621. doi: HYPERLINK "https://doi.org/10.1016/j.clinthera.2016.10.011" It "_blank" 10.1016/j.clinthera.2016.10.011

Falzon, D. et al., 2017. World Health Organization treatment guidelines for drug-resistant tuberculosis, 2016 update. European Respiratory Journal, 49(3), p. 1602308. doi: HYPERLINK "https://dx.doi.org/10.1183\%2F13993003.02308-2016" It "pmc_ext" $\underline{10.1183 / 13993003.02308-2016}$

Harausz, E. et al., 2015. QTc prolongation and treatment of multidrug-resistant tuberculosis. The international journal of tuberculosis and lung diseases, 19(4), pp. 385-391. DOI: HYPERLINK "https://doi.org/10.5588/ijtld.14.0335" \t "_blank" $\underline{10.5588 / i j t l d .14 .0335}$ 
Kemenkes, 2014. Pedoman Nasional Pengendalian Tuberkulosis. Jakarta: Depkes RI. http://hukor.kemkes.go.id/uploads/produk_hukum/PMK_No._67_ttg_Penanggulangan_Tuber kolosis_.pdf

Kemenkes, 2016. Pengobatan Pasien TB Resistan Obat. Jakarta: Departemen Kesehatan Republik Indonesia.

Kemenkes, 2016. Peraturan Menteri Kesehatan Nomor 67 Tahun 2016 Tentang Penanggulangan Tuberkulosis. Jakarta: Depkes RI. http://hukor.kemkes.go.id/uploads/produk_hukum/PMK_No._67_ttg_Penanggulangan _

Tuberkolosis_.pdf

Khan, F. et al., 2018. Moxifloxacin-induced QT interval prolongation and torsades de pointes: a narrative review. Expert Opin Drug Saf, 17(10), pp. 1029-1039. DOI: HYPERLINK "https://doi.org/10.1080/14740338.2018.1520837" It $\underline{10.1080 / 14740338.2018 .1520837}$

Kondoy, P., Rombot, D., Palandeng, H. \& Pakasi, T., 2014. Faktor-Faktor Yang Berhubungan Dengan Kepatuhan Berobat Pasien Tuberkulosis Paru di Lima Puskesmas di Kota Manado. Jurnal Kedokteran Komunitas dan Tropik, 2(1), pp. 1-8. https://ejournal.unsrat.ac.id/index.php/JKKT/article/view/4038/4165

Mihardja, L., Lolong, D. \& Ghani, L., 2015. PREVALENSI DIABETES MELITUS PADA TUBERKULOSIS DAN MASALAH TERAPI. Jurnal Ekologi Kesehatan, 14(4). http://ejournal.litbang.kemkes.go.id/index.php/jek/article/view/4714/4197

Nahid, P. et al., 2016. Official American Thoracic Society/Centers for Disease Control and Prevention/Infectious Diseases Society of America Clinical Practice Guidelines: Treatment of Drug-Susceptible Tuberculosis. Clinical infectious diseases, 63(7), pp. 147-195. doi: 10.1093/cid/ciw376.

Niemeijer, M. et al., 2015. Pharmacogenetics of Drug-Induced QT Interval Prolongation: An Update. Drug Safety, 38(10), pp. 855-867. doi: HYPERLINK "https://dx.doi.org/10.1007\%2Fs40264-015-0316-6" It "pmc_ext" 10.1007/s40264-015$\underline{0316-6}$

Pranger, A. D., 2018. Therapeutic drug monitoring: how to improve moxifloxacin exposure in tuberculosispatients. Rijksuniversiteit Groningen https://www.rug.nl/research/portal/nl/publications/therapeutic-drug-monitoring-how-toimprove-moxifloxacin-exposure-in-tuberculosis-patients(fa9ab83a-e47d-46b3-adfdf484b759b7e0).html

Ramachandran, G. \& Swaminathan, S., 2015. Safety and tolerability profile of second-line antituberculosis medications. Drug safety, 38(3), pp. 253-269. DOI: HYPERLINK "https://doi.org/10.1007/s40264-015-0267-y" It "_blank" 10.1007/s40264-015-0267-y

Thomakos, P. et al., 2013. Cigarette Smoking is Associated with Prolongation of the QTc Interval Duration in patients With Type 2 Diabetes Mellitus. International journal of Endocrinology, p. 329189. HYPERLINK "https://doi.org/10.1155/2013/329189" It "_blank" doi.org/10.1155/2013/329189 
Wallis, R. S., 2016. Cardiac Safety of Extensively Drug-Resistant Tuberculosis Regimens Including Bedaquiline, Delamanid and Clofazimine. European Respiratory Journal, Volume 48, pp. 1526-1527. DOI: 10.1183/13993003.01207-2016

WHO, 2014. Companion handbook to the WHO guidelines for the programmatic management of drug-resistant tuberculosis. Geneva: WHO Document Product Services. https://www.who.int/tb/publications/pmdt_companionhandbook/en/

WHO, 2018. Global Tuberculosis Report 2018, Geneva: World Health Organization. https://apps.who.int/iris/handle/10665/274453

Yoon, H., Jo, K., Nam, G. \& Shim, T., 2017. Clinical significance of QT-prolonging drug use in patients with MDR-TB or NTM disease. Int J Tuberc Lung Dis, 21(9), pp. 996-1001. DOI: HYPERLINK "https://doi.org/10.5588/ijtld.17.0174" It "_blank" 10.5588/ijtld.17.0174 